\title{
O RETORNO DOS ANTIGOS: COMPARTILHAMENTO DO ACERVO FOTOGRÁFICO DE RENATO DELAROLE COM OS ASURINÍ DO XINGU
}

\author{
ALICE VILLELA ${ }^{1}$
}

\begin{abstract}
RESUMO
Este paper ${ }^{2}$ discute a experiência de compartilhamento do acervo integral de fotografias de Renato Delarole produzido entre os Asuriní em fins dos anos 1970 e início dos 1980 - com os Asuriní contemporâneos. De início pretende-se explorar metodologicamente a construção do encontro etnográfico com os Asuriní em torno do compartilhar imagens para, na sequência, dar atenção à recepção asuriní às imagens, momento em que serão abordados os jogos de ver e lembrar os parentes falecidos via fotografias. Diante das imagens dos antigos, os parentes são identificados e suas memórias, evocadas, o que coloca em evidência as tramas do parentesco e os vínculos de pertencimento.
\end{abstract}

\section{Palavras-Chave}

Asuriní do Xingu; Fotografia; Renato Delarole; Compartilhar

\section{THE RETURN OF THE ANCIENTS: SHARING THE PHOTOGRAPHIC COLLECTION OF RENATO DELAROLE WITH THE ASURINIOF XINGU}

\begin{abstract}
This paper discusses the experience of sharing the complete collection of photographs of Renato Delarole produced among the Asuriní in the late 1970s and early 1980s - with the contemporary Asuriní. The first aim is to explore methodologically the construction of the ethnographic encounter with the Asurini around the sharing of images in order to pay attention to the Asuriní reception of the images. It is at this time when the games of seeing and remembering deceased relatives through photographs will be addressed. In front of the images of the ancients, the relatives are identified and their memories, evoked, which highlights the kinship ties and the bonds of belonging.
\end{abstract}

\section{KEY-WORDS}

Asuriní of Xingu; Photography; Renato Delarole; Share

\section{LE RETOUR DES ANCIENS: PARTAGE DU FONDS PHOTOGRAPHIQUE DE RENATO DELAROLE SUR LES ASURINIDU XINGU}

\footnotetext{
${ }^{1}$ Doutora em Antropologia Social- FFLCH/ USP.

${ }^{2}$ Este artigo deriva de reflexões presentes em minha tese de doutorado (ver VILLELA, 2016) realizada no Departamento de Antropologia da USP. Agradeço à Fapesp - Fundação de Amparo à Pesquisa do Estado de São Paulo pela bolsa de estudos (Proc. 2010/19789-5), à Profa. Dra. Sylvia Caiuby Novaes, que orientou o trabalho com generosidade e dedicação, e à Profa. Dra. Regina Müller, que me levou aos Asuriní pela primeira vez e permaneceu como importante interlocutora em diferentes etapas da pesquisa.
} 


\section{RESUME}

Cet article discute l'expérience de partage du fonds intégral de photographies de Renato Delarole - produit parmi les Asurini vers la fin des années 1970 et le début des années 1980 - sur les Asurini contemporains. Pour commencer, on explorera méthodologiquement la construction de la rencontre ethnographique avec les Asurini centrée sur le partage d'images pour, ensuite, porter l'attention sur la réception Asurini aux images, moment où seront abordés les jeux du voir et de se souvenir des parents décédés au moyen de ces photographies. Devant les images des anciens, les parents sont identifiés et leur mémoire, évoquée, ce qui met en évidence les trames de la parenté et les liens d'appartenance.

\section{MOTS-CLE}

Asurini du Xingu ; Photographie; Renato Delarole; Partage

\section{EL REGRESO DE LOS ANTIGUOS: COMPARTIENDO EL ACERVO FOTOGRÁFICO DE RENATO DELAROLE CON LOS ASURINIDE XINGU}

\section{RESUMEN}

El presente artículo discute la experiencia de compartir el acervo integral de fotografías de Renato Delarole, producido entre los Asurirí a finales de la década de 1970 y principios de 1980 con los Asuriní contemporáneos. Primeramente se pretende compartir las imágenes y explorar metodológicamente la construcción del encuentro etnográfico con los Asuriní y luego analizar cómo estos recepcionan las imágenes. Después se realizan los juegos de mirar y recordar a los parientes fallecidos, a través de las fotografías. Al encontrarse frente a las imágenes de los antiguos, los parientes son identificados y sus memorias son evocadas, lo que pone en evidencia las tramas del parentesco y los vínculos de pertenencia.

PALABRAS CLAVE

Asuriní de Xingu; Fotografía; Renato Delarole; Compartir 


\section{INTRODUÇÃO}

Este paper discute a experiência de compartilhamento do acervo fotográfico de Renato Delarole, produzido em fins dos anos 1970 e início dos 1980 entre os Asuriní do Xingu com os Asuriní que atualmente residem nas aldeias Ita'aka e Koatinemo ${ }^{3}$. inicialmente, a proposta de circular estas imagens foi concebida como um dispositivo que me permitisse refletir sobre o modo como os índios se relacionam com imagens fotográficas atualmente. Em trabalhos anteriores (Ver VILLELA, 2015 e 2016) discuti as implicações do primeiro encontro dos Asuriní com fotografias no momento do contato oficial com os padres católicos em 1971. Dizem os Asuriní que, quando os padres católicos encontraram-se com eles e tiraram fotos, a câmera fotográfica sugou o ynga (princípio vital) dos índios, ocasionando doenças e mortes. Quarenta anos depois, me interessava entender se, da perspectiva indígena, estaria a fotografia, de alguma forma, sob a névoa do perigo e da negatividade, ou seus usos e apropriações atuais apontariam para outra direção. Рara além disso, com a circulação do acervo eu pretendia construir o encontro etnográfico em torno de uma provocação4: colocar os Asuriní diante de imagens de si e dos seus "antigos". Experiências de campo anteriores, em que levei imagens fotográficas produzidas por mim e também por Delarole, instruíram-me, ainda que de forma não sistemática, a respeito da produtividade do emprego de fotografias em situações de encontro etnográfico ${ }^{5}$. Portanto, a experiência de compartilhamento do acervo de Delarole me permitiu, ao mesmo tempo, explorar metodologicamente o uso da fotografia na pesquisa de campo e em situações de encontro etnográfico, e observar etnograficamente o que aconteceu no contato dos Asuriní com as imagens dos "antigos", esses dois tópicos guiam as reflexões a serem apresentadas neste texto.

O conjunto de fotografias de Renato Delarole produzidas entre os Asuriní do Xingu compreende pouco mais de 750 imagens, originalmente produzidas em suporte analógico. São cerca de 450 slides e 300 negativos, contatos e ampliações PB. Nos rolos de filme, estão retratados variados aspectos da vida dos Asuriní do Xingu entre 1977 e 1986, período em

\footnotetext{
${ }^{3}$ Os Asuriní do Xingu são um povo Tupi que vive na margem direita do rio Xingu, no Pará, na Terra Indígena Koatinemo. Divididos em duas aldeias, os Asuriní são hoje cerca de 200 pessoas.

${ }^{4}$ Este é o objetivo de Edgar Teodoro da Cunha, Ana Lúcia Ferraz e Rose Satiko Hikiji (2006), quando propõem aos seus diferentes interlocutores a apropriação do audiovisual. O fazer antropológico, neste caso, está orientado a partir de uma proposição e uma provocação que considera, inclusive, o lugar do antropólogo na relação com o grupo.

${ }^{5}$ Como observa Maresca (1996), ao tecer uma história do olhar fotográfico na antropologia, imagens possuem o potencial reflexivo em situações de encontro etnográfico e são um meio privilegiado para a compreensão cultural.
} 
que o fotógrafo esteve entre os índios. Dentre todo o acervo, uma ênfase especial é dada aos temas do xamanismo e arte gráfica, tópicos de pesquisa da antropóloga Regina Müller ${ }^{6}$, a quem o trabalho fotográfico de Delarole entre os Asuriní sempre esteve atrelado. Por meio de Müller, Delarole é introduzido no campo e, em companhia dela, realiza todas as viagens, inclusive com permanência de dois longos períodos de dez meses, em 1978 e 1979, quando permaneceram quase que todo o tempo residindo no Posto Indígena Koatinemo, nas margens do igarapé Ipiaçava, na aldeia do Koatinemo Velho.

Em 2006, as fotografias foram organizadas e digitalizadas em razão do edital "Mapeamento, Documentação e Apoio ao Patrimônio Cultural Imaterial" do IPHAN. O projeto teve como objetivo tratar, digitalizar e organizar o acervo sobre o patrimônio imaterial asuriní, incluindo, não apenas fotografias, mas também vídeos em super-8, Betacam e VHS, além de material de áudio em fita K7 e em rolo obtidos por gravador Nagra, reunidos nos últimos 30 anos pela pesquisadora Regina Müller. O trabalho foi realizado pela antropóloga junto com uma equipe do Instituto de Artes da Unicamp e do Museu de Arqueologia e Etnologia, MAE - USP, a qual tive o prazer de integrar ${ }^{7}$. As imagens em suporte original foram doadas ao Museu do Índio da Funai, sediado no Rio de Janeiro.

Quase dez anos depois, em maio de 2015, em trabalho de campo para minha pesquisa de doutorado (Ver VILLELA, 2016), levei o acervo integral das fotografias para os Asuriní em impressões em papel fotográfico (tamanho $15 \mathrm{~cm} \times 21 \mathrm{~cm}$ ). Embora todas as fotografias já estivessem disponíveis em suporte digital, a opção por levar fotos em papel me conferiu maior agilidade para o trabalho na aldeia - local onde usar computador nem sempre é fácil. Durante dois meses as aldeias Ita'aka e Koatinemo se ampliaram com a presença dos "antigos" presentes nas fotografias. Imagens de parentes engendraram jogos de ver e lembrar que reforçaram a memória e os vínculos de pertencimento

\section{A CONSTRUÇÃO DO ENCONTRO ETNOGRÁFICO EM TORNO DO COMPARTILHAR IMAGENS}

A experiência de levar para as aldeias o acervo integral de fotografias de Delarole se constituiu como uma forma de partilhar o conhecimento produzido sobre os Asuriní com eles, tendo em vista que todas as imagens foram produzidas no âmbito de pesquisas acadêmicas da antropóloga Regina Müller. Assim como Rouch inclui o retorno de seus filmes aos grupos estudados como forma de criar um diálogo efetivo com as sociedades entre as quais trabalha, indo além do mero feedback (CF. CUNHA, FERRAZ e HIKIJI, 2006), o retorno

\footnotetext{
${ }^{6}$ Ver, por exemplo, Müller (1992 e 1993).

${ }^{7}$ Em 2006, recém-saída da graduação em Ciências Sociais na Unicamp, eu trabalhara no projeto de digitalização e organização das imagens ao mesmo tempo em que preparava um projeto de mestrado (Ver VILLELA, 2009). As fotografias foram o meu primeiro acesso aos Asuriní.
} 
de imagens aos Asuriní foi pensado como uma forma de partilhar com o grupo a produção de representações a seu respeito, e, sobretudo, de criar situações em que eu pudesse observar a forma como eles se apropriam dessas imagens segundo uma lógica própria.

A recepção asuriní às imagens foi marcada por interesse e curiosidade, principalmente dos velhos, que se mostraram bastante disponíveis para o trabalho com as fotografias. Sessões de manuseio, exame, observação e deleite com as fotos foram realizadas nos espaços privados dos núcleos residenciais e nos espaços externos a eles associados, como cozinhas, pequenos pátios e casas de farinha. Com algumas famílias foi possível realizar um trabalho continuado, o que possibilitou a criação de um ambiente de confiança e intimidade, atmosfera que favoreceu a enunciação de relatos pessoais, evocados pelas fotos dos familiares.

Sessões de fotografias constituíram bons pretextos para conversas sobre diversos aspectos da vida social asuriní. Em razão da riqueza de detalhes que apresentam, fotografias estimularam a curiosidade de jovens a respeito da vida ritual, produção de objetos e utensílios, processamento de alimentos e, sobretudo, acerca das relações de parentesco que iam sendo estabelecidas com as pessoas presentes nas imagens. A densidade de informações e descrições que me eram fornecidas em pouco tempo, aliada à disponibilidade dos índios em explicar o que estava retratado nas imagens e em responder às minhas perguntas, lançou luz para o potencial da fotografia como instrumento de transmissão de conhecimentos, do qual muito me beneficiei.

Cheguei ao campo com a proposta metodológica de uso das fotografias do acervo de Delarole em aberto. Embora tivesse uma série de questões em mente e algumas propostas de atividade com o acervo, não me preocupei em levar um plano de trabalho fechado, pois acreditava que deveria, primeiramente, observar a resposta asuriní às imagens. Como já se mencionou, minha intenção inicial era criar situações de interação dos Asuriní com as fotografias. Sabia, de antemão, do perigo associado às imagens de pessoas que já morreram e, respeitando as regras e limites apresentados pelos Asuriní, pretendia investigar a existência ou não de tabus relacionados aos retratos dos mortos ${ }^{8}$. Ademais, tinha a expectativa de realizar um trabalho um pouco mais aprofundado com os índios interessados, de forma a selecionar, em todo o acervo, as fotografias mais significativas, e coletar relatos, propondo que, ocasionalmente, organizassem parte do acervo segundo parâmetros próprios.

Рara uma possível organização do grande volume de imagens, uma referência metodológica importante, consultada antes da viagem de campo, foi a pesquisa de Fabiana Bruno. Em sua tese de doutorado, intitulada "Fotobiografia, por uma metodologia da

\footnotetext{
${ }^{8}$ Tratarei deste tema mais adiante.
} 
estética em antropologia" (2009), a pesquisadora aposta em uma proposta metodológica que confere prioridade e confiança ao trabalho das imagens. A partir de fotografias de memórias de cinco pessoas idosas da cidade de Jaguariúna, Bruno realiza um percurso metodológico de natureza visual trabalhando com conjuntos fotográficos compostos por 20, 10 e 3 fotografias de cada um dos colaboradores da pesquisa. Diz a autora: "Por serem carregadas de memórias, elas, as imagens, puderam, diferentemente do verbal, 'refletir' e 'pensar', 'redescobrir', e 'esquecer', a memória de pessoas idosas" (2009, p. VII). O trabalho de Bruno me iluminou metodologicamente com propostas de seleção e organização de imagens. No entanto, a minha proposta de trabalho tinha, de início, uma diferença de orientação em relação ao que ela propunha. Embora pretendesse dar confiança ao trabalho com as imagens, não me interessava pesquisar como as fotografias "pensam", "refletem" e "esquecem" a memória de pessoas, mas como imagens agem (GELL, 1998) "provocando", "despertando", "originando", "ativando" efeitos, memórias e reflexões nas pessoas.

Não se tratava de pensar a relação dos Asuriní com quaisquer tipos de imagens fotográficas, mas de propor o confronto com imagens de si e de seus "outros", incluindo aí os vivos e os mortos. Pessoalmente, trabalhar com o conjunto fotográfico de Delarole era uma espécie de retorno a um material sobre o qual eu me debruçara extensivamente há cerca de dez anos, na ocasião da realização de um trabalho que marcou a minha entrada no campo, o já citado projeto que digitalizou o acervo de pesquisa de Regina Müller viabilizado por edital do Iphan.

As imagens de Delarole funcionaram como objetos disparadores de memórias. Vendo as fotos, os Asuriní não me falavam sobre o fotógrafo ou as condições de tomada das fotografias, não tentavam me fornecer coordenadas espaço-temporais em que as fotos foram tiradas, nem comentavam os objetos retratados ou as ações realizadas no momento do registro, a não ser que eu os questionasse a respeito. Ao verem as fotografias, imediatamente identificavam as pessoas retratadas e faziam questão de situá-las nas tramas do parentesco. Alguns, vendo imagens de si quando novos, reconheceram-se e comentaram experiências do passado. Outros, essencialmente os velhos, recordaram de esposas e esposos, ao verem retratados ex-cônjuges que já faleceram, e produziram relatos carregados de afeto e saudades. Entre os que viveram no tempo em que Delarole fotografou, as fotografias funcionaram como detonadores de memória, em que a experiência mais marcante consistiu na possibilidade de avivar feixes de relações com parentes e tornar presentes vínculos de pertencimento.

Fotografias atuaram de forma fecunda na produção de relatos, expressão das memórias ativadas. Este uso da fotografia não é, de longe, uma novidade; diversos estudos empregaram a fotografia aliada a registros orais. Já em 1967, John Collier Jr. dedicou um capítulo de sua obra Antropologia visual: a fotografia como método de pesquisa (1973) ao 
uso de imagens fotográficas durante entrevistas com indivíduos dos grupos pesquisados, focando as contribuições que poderiam trazer para os estudos antropológicos. A historiadora Miriam Moreira Leite (2001[1993]) assinalou em sua obra que, ao olhar uma imagem, não é ela que se vê, mas sim outras que se desencadeiam na memória. A cientista social Olga Von Simson (2005) constatou que seus depoentes, no caso da sua pesquisa do samba paulista, utilizavam fotografias como recursos detonadores de memórias, e, além de as fotografias enriquecerem a narrativa, também davam mais segurança ao processo de rememoração. A possibilidade de uso da fotografia como enriquecedora de registros orais a coloca, na maior parte dos casos, como secundária. Uma diferença crucial entre estas abordagens e a que empreendi consiste no fato de que, neste trabalho, fotografias foram empregadas como método de abordagem para investigar justamente a relação dos índios com a fotografia, sendo, ela, método e tema do estudo. A questão que a fotografia coloca para os Asuriní reside justamente no que ela faz. Portanto, a capacidade de acionar memórias, artifício metodológico para alguns, é um dos problemas centrais que me interessavam ${ }^{9}$.

Ao verem as imagens "dos antigos" inúmeros relatos foram enunciados. Muitos parentes foram vistos e lembrados. As lembranças das esposas e esposos, tios e tias, primos e primas dentre muitos outros parentes se faziam presentes via relatos de forma simultânea, apontando para o fato de que as memórias deviam ser tomadas, mais como um processo de "criação de uma realidade", do que como um documento e testemunho que me auxiliariam a reconstituir o passado. Parentes falecidos conviveram no mesmo espaço-tempo que os Asuriní de hoje, o da lembrança do presente.

A fotografia reproduzida abaixo traz um pouco do ambiente de intimidade em que se realizaram as sessões fotográficas com Marakauá e Mure'yra. Como casal, pude verificar, tanto a maneira em que eles empregaram as fotografias para refazer laços e vínculos de parentesco, ao elaborar sua seleção do acervo - a que chamei de "álbuns" (Ver, VILLELA, 2016, capítulo 4), em razão da presença massiva de familiares -, como também entender que as fotos mais caras a eles eram as que traziam lembranças de experiências partilhadas com ex-cônjuges.

\footnotetext{
${ }^{9}$ Se o potencial de despertar memórias pode ser verificado entre outros campos de estudo que empregam a fotografia aliada a relatos orais, a ênfase asuriní em sua agência aponta justamente para o fato de que ali fotografias entram num regime de imagem muito específico. Para uma reflexão mais aprofundada acerca do regime e agência das imagens entre os Asuriní, ver Villela (2015 e 2016).
} 


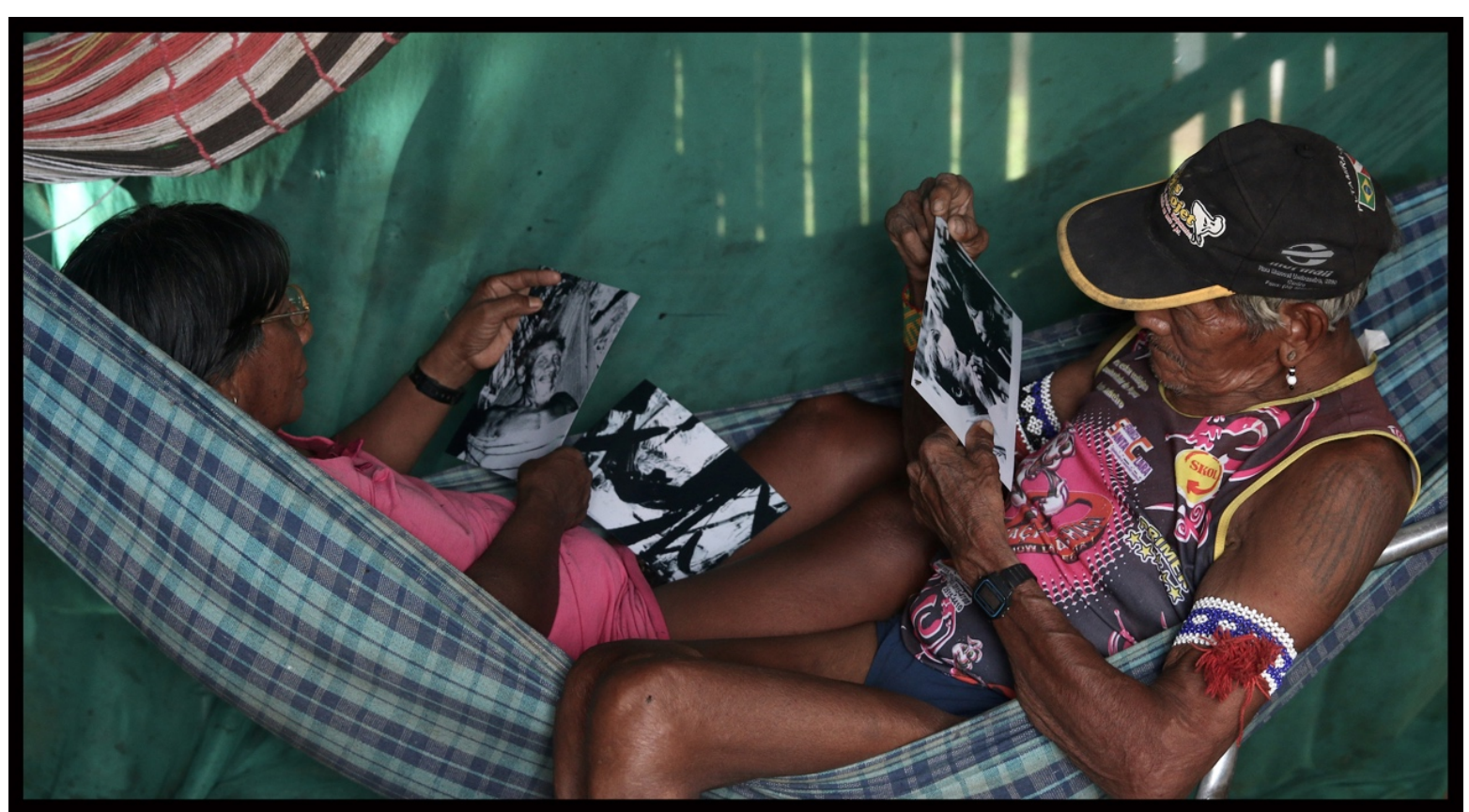

Imagem 1: Mure'yra e Marakauá durante sessão com as fotografias na residência do casal. Foto: Alice Villela, maio de 2015.

Existe uma certa relação entre o que as fotografias evocaram entre os Asuriní e os retratos de família abordados por Miriam Moreira Leite (2001[1993]). O entusiasmo com que as fotografias dos "parentes" foram recebidas pelos índios nos faz lembrar do fascínio que exercem os retratos dos álbuns de família nos grupos em que Moreira Leite pesquisou. A autora comenta que a atração teria sido observada por Bourdieu e seus discípulos quando consideraram o álbum de família um "monumento funerário freqüentado assiduamente". Dubois (2014[1990]), ao dar ênfase à unicidade referencial que literalmente se propaga por contato e pelo jogo da contiguidade material entre imagem e pessoa retratada, cita os retratos de família, ao comentar os usos que tendem a atribuir à foto uma força particular, algo que faça dela um verdadeiro objeto de crença, para além de qualquer racionalidade, de qualquer princípio de realidade. Os álbuns de família, guardados e cultivados como uma "múmia dentro de uma caixinha", são abertos com emoção "[...] numa espécie de cerimonial vagamente religioso, como se tratasse de convocar os espíritos" (Op. cit., p. 80). Neste tipo de álbum, fotos são como traços físicos de pessoas singulares, que guardam relações singulares com aquele que olha as imagens. Dubois fala em verdadeiro culto a fotos de família, e, nos álbuns, como objetos fúnebres, semelhantes aos kolossói - substitutos do morto na Grécia Antiga analisados por Vernant (1990[1973]).

Se o culto aos álbuns de família como objetos fúnebres semelhantes aos kolossói nos aproximaria dos gregos na Antiguidade, a elaboração dos "álbuns" asuriní muito pouco se avizinham às nossas práticas de guardar a memória dos parentes via fotografias. Embora tenha sido salutar ver os mortos nas imagens, por se tratarem de mortos recuados no tempo, guardar imagens ou objetos do morto não é uma prática corrente pois, após a morte, tudo o 
que lembra o morto deve ser destruído. O emprego de fotografias para lembrar dos "parentes" não é uma prática asuriní, muito pelo contrário, foi a reação e o efeito a uma provocação.

O método de pesquisa de campo proposto, espécie de "provocação-observante", consistiu em compartilhar as imagens e depois observar o que a fotografia faz, o que engendra, de que modo atua, o que efetua, como age, procede, pratica, processa e o que aciona. E o que ela fez, essencialmente, foi trazer os "antigos" pela mão das memórias a eles vinculadas. Durante alguns dias, a aldeia asuriní se ampliou, vivemos envoltos da presença dos "antigos", não a presença espectral, nem a presença em carne e osso, mas a presença em pensamento, lembrança e imagem, via fotografia e memória.

\section{VER E LEMBRAR: A MEMÓRIA DOS ANTIGOS}

"Antigo é assim. É bom ver quem era vivo". (Apebu, ao ver fotografias de Delarole)

As pouco mais de 750 imagens produzidas por Renato Delarole entre 1977 e 1986 difundiram-se de casa em casa nas aldeias Ita'aka e Koatinemo durante os meses de maio e junho de 2015. De crianças a velhos, todos queriam ver os "antigos". As fotografias eram chamadas geralmente de bavarayngava, em que bava = Asuriní que já morreram ou "antigos" na tradução para o português, e ayngava = imitação, imagem ${ }^{10}$.

A presença massiva de pessoas falecidas nas fotografias, ao contrário do que poderíamos supor, não causou incômodo algum; diziam sempre que aquelas pessoas "morreram faz tempo" e as memórias a eles associadas poderiam ser lembradas, bem como seu nome, sem prejuízos. Sabe-se que os Asuriní tradicionalmente trocam de nome com a morte de um parente; neste caso, substituem seus nomes por outros que pertenceram a mortos mais recuados no tempo ${ }^{11}$. O tabu em relação ao nome do morto recente continua vivo, e o perigo existe pois a desintegração da pessoa libera o espectro anhynga. Neste caso, pronunciar o nome do morto recente, assim como ver a sua fotografia ou simplesmente se lembrar dele, representa um risco iminente pois o pensamento, o nome e a imagem podem atrair seu anhynga para perto da aldeia.

Em relação à enunciação do nome dos falecidos, observou-se que, ao comentar sobre as pessoas retratadas nas imagens entre eles, não pronunciavam os nomes próprios

\footnotetext{
${ }^{10}$ Para uma problematização dos conceitos asuriní para o campo da imagem com ênfase na ideia de ayngava ver Villela, 2016, capítulo 1.

11 Ver Souza (1994), que estudou a nominação entre os Asuriní do Xingu e fez uma etnografia com material de campo de fins dos anos 1980 e início dos 1990.
} 
dos falecidos, servindo-se sempre dos termos de parentesco tendo a si mesmos ou a terceiros como referência. No entanto, não ofereciam resistência em mencionar os nomes quando questionados por mim ou pelas crianças e jovens Asuriní. No caso de o nome já pertencer a alguma pessoa viva, diziam o nome do morto sem qualquer impedimento e sem que eu ou algum Asuriní solicitássemos; neste caso, insistiam em explicar o grau de parentesco entre a pessoa viva e o morto.

Fotografias despertaram memórias dos parentes, saudades de entes queridos, lembrança de situações marcantes, e geraram comentários e reflexões a respeito de como era a vida dos Asuriní no Koatinemo Velho e como é a vida dos Asuriní de hoje. Os velhos não ficaram satisfeitos em ver as fotografias apenas uma vez, queriam apreciá-las e manuseá-las repetidamente, de modo que o movimento de ver e lembrar dos parentes retratados era reforçado. A cada novo encontro com as mesmas imagens, outras histórias surgiam. Os mais novos viram muitos de seus parentes pela primeira vez e, cheios de curiosidade, remetiam-se aos velhos requisitando explicações.

Embora as sessões de apreciação, manuseio e exame das fotografias tenham sido realizadas nos núcleos residenciais, ou seja, no meio de crianças, adultos e velhos, seus efeitos mais significativos puderam ser observados entre os velhos com mais de 60 anos, que, não apenas dispunham de tempo para ver e rever as imagens, como eram adultos quando Delarole fotografou e conheciam a maior parte das pessoas retratadas. Para este grupo de índios, as fotografias ativaram memórias de relações, vínculos de pertencimento, elos, eventos e histórias ocorridas nas imediações das relações próximas com os "antigos" Asuriní.

\section{Lembranca dos maridos}

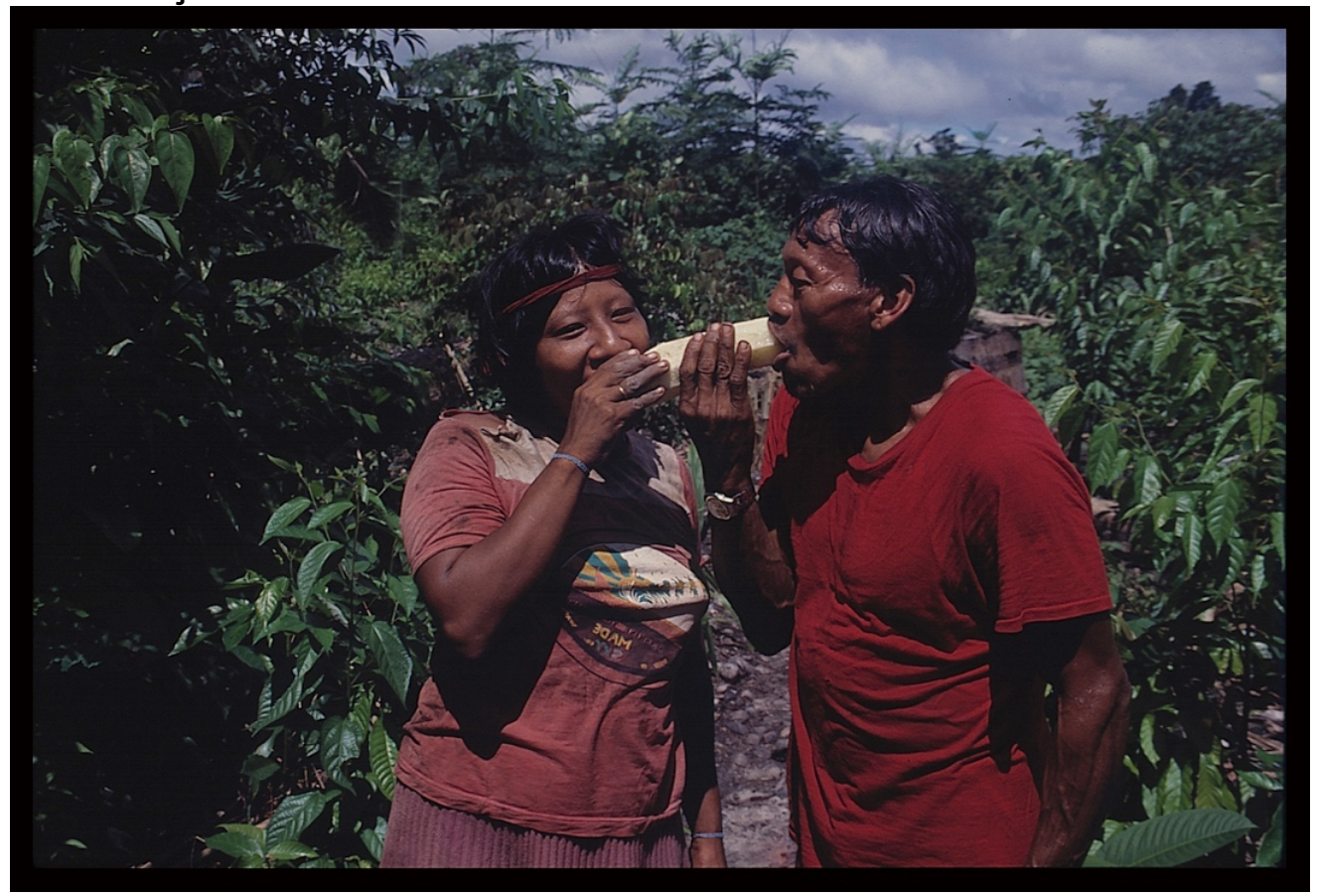

Imagem 2: Mure'yra e Marakauá posam para foto após arrancar mandioca na roça. Foto: Renato Delarole. 
A foto acima ${ }^{12}$ traz Marakauá e Mure'yra numa situação de descontração. O fotógrafo Delarole é cumplice do momento em que o casal brinca com a mandioca doce (maniakal) no retorno da roça. Quando, na casa dos dois, em uma das sessões com o acervo, eu me deparei com esta fotografia, separei-a de imediato. Talvez ela fosse umas das escolhidas por mim, num âmbito somente pessoal, por expressar um momento cotidiano em que o casal (que se tornou próximo a mim) se exibe em atitude carinhosa e posada. Mostrei a Marakauá esperando algum sorriso de aprovação, mas minha ação não teve efeito algum. O que ela queria ver eram as fotografias dos seus parentes "antigos", especialmente dos excônjuges já falecidos, aos quais ela se referia como mukuĩjererakwara, "meus dois maridos".

Ao final da sessão de fotos com Marakauá, disse-lhe que ela podia escolher algumas imagens para ficar como um presente, e, dentre todas as imagens, a índia escolheu uma. Na foto eleita (reproduzida a seguir), um bloco de seis pessoas dança durante ritual xamanístico. Marakauá está abraçada ao seu marido mais velho, Avona, que canta e toca o yapu, chocalho usado pelo pajé durante o ritual. O marido novo, l'iva, atua como ajudante do xamã (vanapy) e está posicionado do lado direito de Avona. Do lado esquerdo de Marakauá está Apeuna; ambas estão paramentadas com penas de gavião na cabeça pois atuam na função de uirasimé, mulheres cuja principal atividade na festa é preparar as refeições rituais - mingaus para os xamãs, participantes e espíritos.

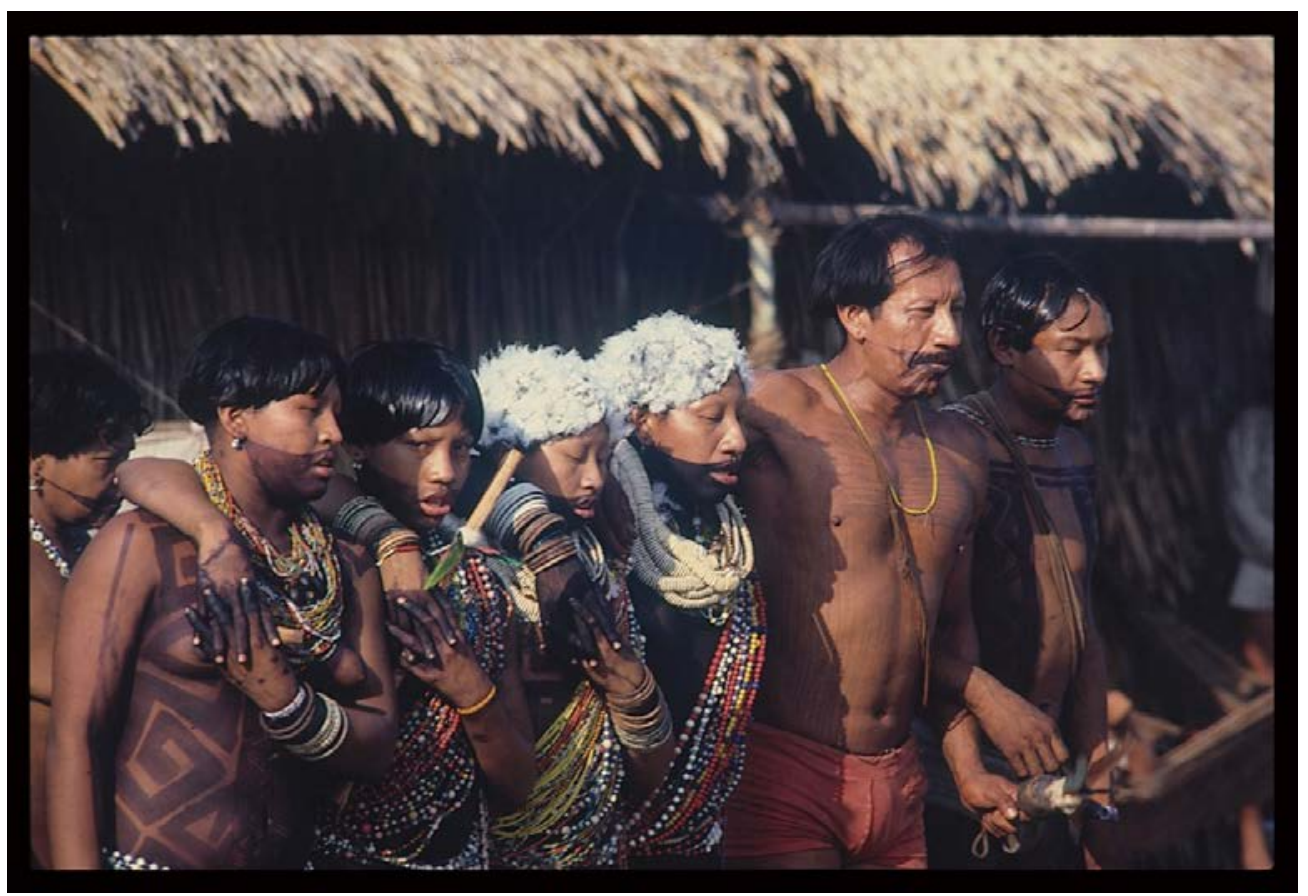

Imagem 3: Fotografia escolhida por Marakauá. O homem de calção vermelho é Avona; ao lado direito dele, I'iva; ambos foram maridos dela. Foto: Renato Delarole.

\footnotetext{
${ }^{12}$ As fotografias de Delarole foram tiradas entre 1977 e 1986; não foi possível datar foto por foto.
} 
À esquerda de Apeuna estão Matuia e Mará, dançarinas que auxiliam no canto e na dança. Todas as mulheres estão enfeitadas com pinturas (juaka), colares de dente de macaco (kajyja), colar cruzado de miçanga (muyjuvaia), colar de cintura de miçanga (ka'apuava), maritá (pulseira de côco babaçu com osso de mutum, mytukyga) e brincos de miçanga (namikwayma). Todos dançam posando o olhar na altura do chão com expressão de concentração, e apenas Matuia olha para a câmera. No relato, incitado pela fotografia, Marakauá conta do casamento com os dois maridos retratados.

\begin{abstract}
Jemyga'ara ${ }^{13}$, esse aqui que me criou [apontando para Avona na foto] ${ }^{14}$. Ele só dá comida primeiro pra mim, porque minha irmã [Moteri, hoje com 68 anos] largou ele. Aí ele ficou sozinho, ficou triste, sente falta dela, não fica quieto. Foi atrás de tapy'yia [branco]. Tapy'yia atirou nele e quase mata. Aí meu pai falou pra minha irmã: "Por que tu deixou ele?". Aí meu pai chamou ele [Avona] e disse: "Fica com essa minha filha mais novinha, vê se ela vai te deixar também". Aí ele vem, ficou comigo, só que nem como filha até eu ficar moça. Aí eu fiquei moça e fiquei com ele por muito tempo. Juntei com ele lá no Ipixuna, fiquei um "tempão" com ele. A gente fazia muita festa lá.
\end{abstract}

[...] Lá no Koatinemo Velho, aquele marido meu, novinho [I'iva], foi meu marido velho [Avona] que chamou ele pra ficar comigo. Ele [marido novo] já estava rapazinho pra ficar comigo. Aí meu marido velho chamou ele pra morar com a gente porque ele queria casar com uma outra mulher nova.

O depoimento de Marakauá é muito interessante pois, ao narrar em primeira pessoa os episódios envolvidos nos seus enlaces com os dois maridos, ela nos informa a respeito do modo como os Asuriní procediam tradicionalmente nos arranjos matrimoniais, nos chamados casamentos geracionais, ou seja, com cônjuges de duas gerações, que podia ser realizado tanto na forma poligínica quanto na poliândrica (MÜLLER, 1993, p. 64). Matuia, a tradutora do relato, explica: "Asuriní era assim: quando o homem queria mulher nova, primeiro ele tinha que ficar com a mãe, criar como filha a menina [filha da mãe] até ela ficar moça, depois casar com ela". Nesta relação, o cônjuge mais novo, homem ou mulher, chama de jemyga'ara quem o criou, e este utiliza o termo jeremymĩgá para se referir "àquele que foi criado por mim".

O casamento entre as jeremyga'ara e jeremymígá parece ter sido preferencial tradicionalmente. Müller (1993, p. 71) sugere que as regras de casamento entre os Asuriní estavam baseadas nas diferenças de sexo e idade e não na classificação dos indivíduos pelo parentesco. A união entre 'aquela ou aquele que me criou' e 'aquela ou aquele que foi criado por mim', com prioridade para o filho adotivo, filho da esposa ou do marido, era prática muito comum. O que acontecia com a pessoa, para ambos os sexos, ега o seguinte: quando adolescente, casava com um cônjuge mais velho, e, quando maduro, contraía casamento com um cônjuge mais novo.

\footnotetext{
${ }^{13}$ Müller (1993, p. 71) utiliza o termo jeremygara para designar "aquele que me criou". Acredito se tratar do mesmo termo, apenas com uma diferença no modo de grafar.

14 Algumas das informações adicionais entre colchetes, que visam auxiliar na compreensão do relato, foram fornecidas pela tradutora, Matuia.
} 
Veveí, de 65 anos, também viu as fotografias, uma a uma, procurando seu marido falecido. A índia separou as imagens de seu ex-cônjuge (Momuna) e pediu de presente. "Meu marido, eu estou com saudade. Eu quero mesmo meu marido", comentou Veveí ao ver a fotografia de Momuna (imagem 5). Ela pegou o conjunto das fotos, abraçou e brincou dizendo que ia dormir com elas. A memória da morte trágica de Momuna veio à tona. Um dia ele foi para a roça e não voltou mais. Foi encontrado horas depois com um tiro na garganta. Os Asuriní localizaram a espingarda dele apoiada em uma árvore e o corpo no caminho para a roça. As diversas versões indicam que ele teria sido assassinado, mas cada uma possui um ponto de vista de quem seria o culpado. A morte teria sido causada por uma disputa por mulher.

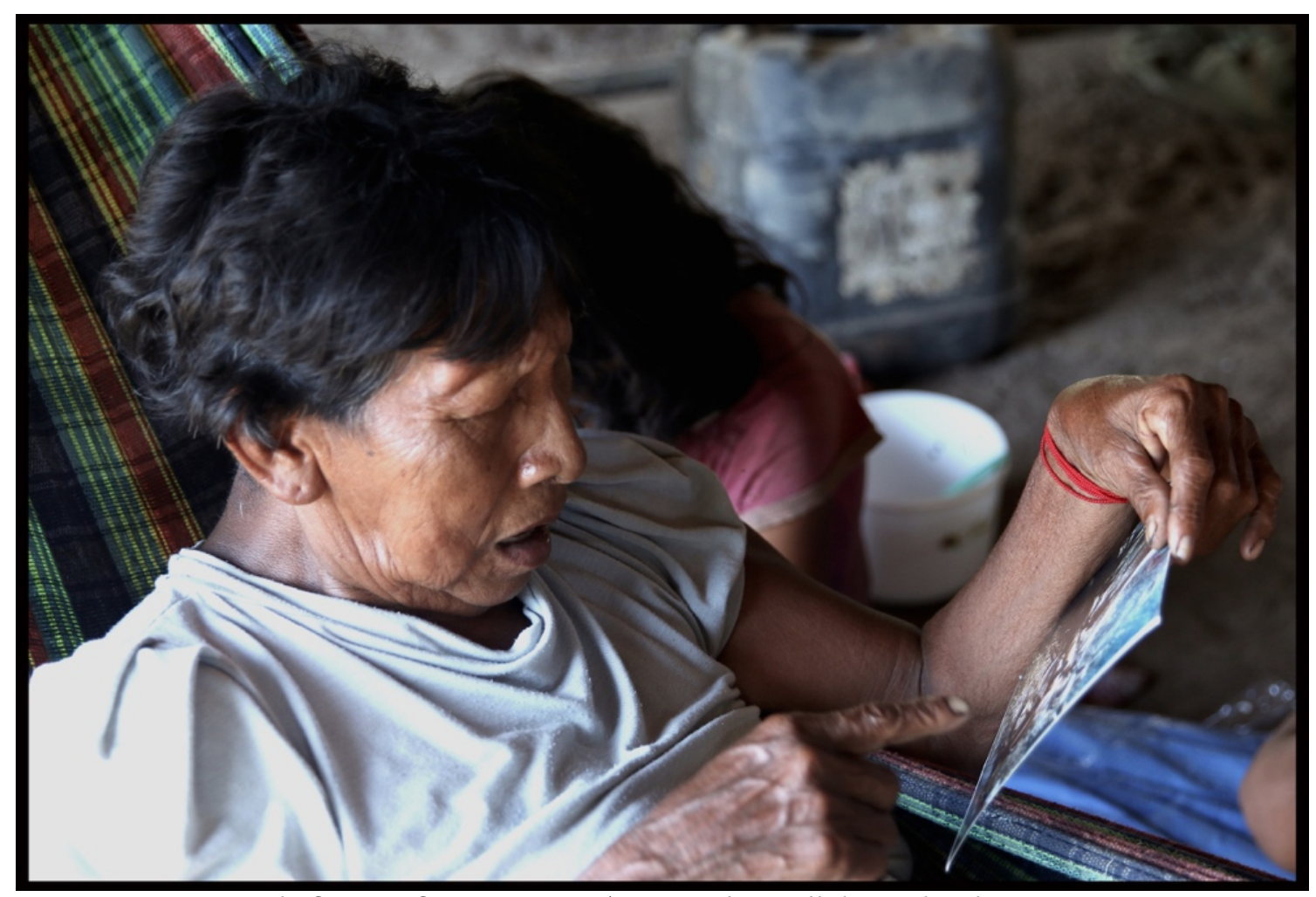

Imagem 4: Sessão de fotografias com Veveí. Foto: Alice Villela, junho de 2015. 


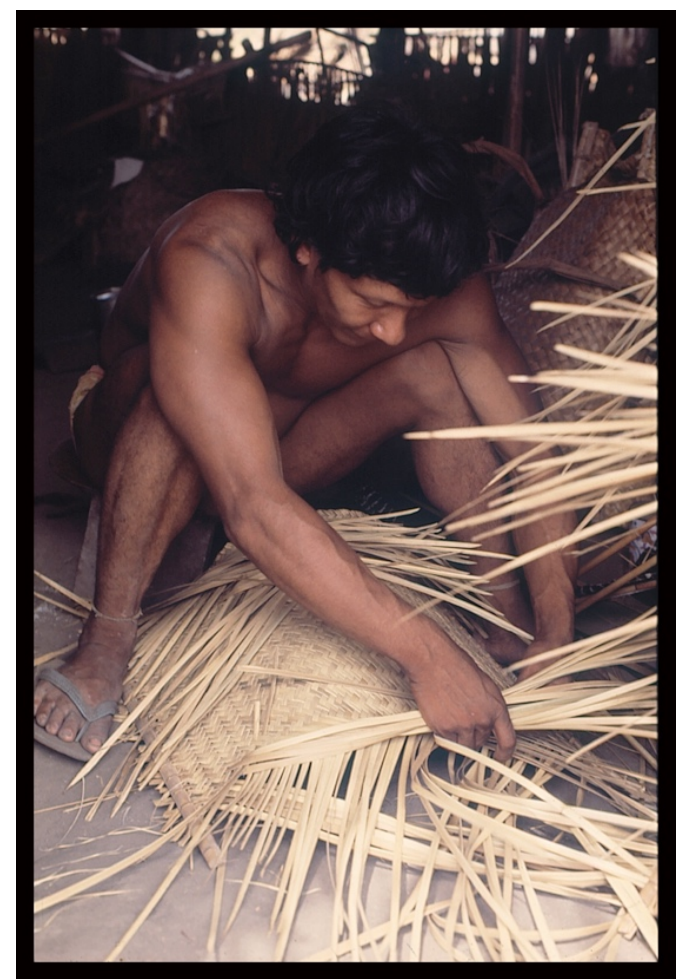

Imagem 5: Momuna. Foto: Renato Delarole

\section{FOTOGRAFIA E PERTENCIMENTO NAS TRAMAS DO PARENTESCO}

Ao verem as fotografias, os Asuriní se concentraram em identificar as pessoas retratadas e situá-las na trama de relações de parentesco. Quem primeiro indicou o elo entre parentes via fotografias foi o ancião Mure'yra, que foi o primeiro a ver e a manusear o acervo de Delarole. Do primeiro bloco de fotografias, cerca de 60 imagens impressas foram vistas uma a uma. Cada imagem era examinada com cautela pelo índio. Lentamente começou a me dizer: "jereky'yra", "jera'yra", "jesemere"15, apontando para as pessoas retratadas nas imagens. O esforço de Mure'yra foi dispendido, todo o tempo, a tentar reconhecer quem estava presente no retrato.

Bueno (2015) argumenta que o parentesco, como é sabido, é socialmente construído e se constitui enquanto tal a partir de um arcabouço de informações compartilhadas entre as pessoas que são feitas parentes. Neste momento, a relação entre parentesco e memória é posta, uma vez que ele parece sempre depender dessas informações, ou conhecimentos, do que veio de um tempo - imediatamente ou não pretérito. Ela vai dizer que a memória familiar, ou genealógica, desempenha, nesse sentido, um importante papel na estruturação do tempo doméstico e da coletividade, em algumas sociedades. Nesses casos, o tempo não é organizado em função de fatos históricos, mas das lembranças de momentos significativos e marcantes na lembrança familiar. Nascimentos,

15 Termos de parentesco para o ego masculino, respectivamente "meu irmão mais velho", "meu filho" e "meu primo". Para terminologia completa, ver Müller(1993, p. 309). 
alianças, mortes, aquisição de terras, entre outros, são eventos que marcam o tempo e se tornam referências compartilhadas (BUENO, 2015, p. 9).

Ao identificarem as pessoas presentes no retrato lembranças eram acionadas. Se as fotografias agiram como gatilhos para os disparos da memória, levar mais de 700 imagens funcionou como uma rajada de tiros em sequência, gerando feixes de lembranças combinados e sobrepostos que se teciam de forma ativa, plástica e criativa. Os fios em que se teciam fotografias e memórias eram feitos da matéria do afeto e da emoção, e era isso que os Asuriní estavam me mostrando ao me indicar que as imagens significativas eram as de seus entes queridos, principalmente maridos e esposas.

Marakauá explicou que, quando era nova e via fotos de pessoas já falecidas, ficava com muita saudade; agora, que está velha, não sente mais saudades; as fotografias evocam "só lembrança". Diferentemente da índia Veveí que repetiu mais de uma vez, ao ver a imagem de seu ex-marido falecido, que tinha saudades dele. Ao final da apreciação de todo o acervo de Delarole, Marakauá relata que gostou demais de ver as fotografias dos parentes pois: "[...] hoje morreu tudinho, não tem quase parente vivo".

Desde o contato oficial com os brancos em 1971 a vida dos Asuriní mudou bastante. O decréscimo populacional pós-contato e quase extinção física do grupo se fizeram recuperar em meados dos anos 1980. O crescimento demográfico, segundo Müller (2002), ocorreu com transformações nas práticas tradicionais e na organização social, como a alteração do grupo familiar pelo aumento de filhos na família nuclear e o abandono integral das antigas práticas de controle de natalidade. Observou-se, também, o decréscimo no número de adultos e velhos, o que implicou o desaparecimento de muitos xamãs e líderes de grupos domésticos.

Atualmente três quartos da população asuriní são crianças e jovens, e pouco mais de uma dezena são velhos com mais de 60 anos. Para esses poucos velhos, como Marakauá, Veveí e Mureyra, os Asuriní de hoje vivem de um modo completamente diferente do que viviam no momento em que Delarole fotografou. A começar pelo convívio intenso com os brancos, o que nos últimos dez anos foi caracterizado por mudanças ainda mais velozes por conta do empreendimento UHE Belo Monte na região ${ }^{16}$. As regras de casamento também são bem diferentes. Atualmente, nos novos matrimônios, as relações jemyga'ara / jeremymĩgá relembrados por Marakauá via fotografias foram praticamente extintas ${ }^{17}$; os

\footnotetext{
${ }^{16}$ A usina de Belo Monte começou a ser construída em 2010 pela Norte Energia, empresa de capital misto que venceu o leilão para a construção da obra, e, embora nenhum dos grupos indígenas do médio Xingu tenha tido suas terras alagadas, os impactos socioeconômicos são enormes.
}

${ }^{17}$ Apenas um homem maduro, Atyva, de 33, seguiu esta regra e casou-se com Taymira (37 anos), e sua filha, Kereca (21 anos), criando primeiro a menina como filha adotiva. 
casamentos realizados nos últimos anos são monogâmicos e entre cônjuges da mesma faixa de idade.

Por tudo isso é possível afirmar que a presença dos parentes via fotografias representou uma espécie de conforto (e refúgio) aos velhos, que têm dificuldades de compreender e de se situarem na atual conjuntura caracterizada por transformações profundas e aceleradas. Longe do espectro do perigo e do roubo do ynga (princípio vital), a que os asurini associaram a fotografia no contato, a circulação do acervo de Delarole apontou para a potencialidade e a positividade da fotografia em afirmar laços e vínculos de pertencimento por meio das memórias do passado relacionadas aos antigos presentes nas imagens.

\section{REFERÊNCIAS}

BRUNO, Fabiana. Fotobiografia. Por uma metodologia estética em antropologia. 2009. Tese (Doutorado em Multimeios) - Programa de Pós-Graduação em Multimeios, Instituto de Artes da Universidade Estadual de Campinas, Campinas, 2009.

BUENO, Ana Cecilia Venci. Fios de memórias. Um estudo sobre parentesco e história a partir da construção da genealogia manoki (irantxe). 2015. Tese (Doutorado em Antropologia Social) - Programa de Pós-Graduação em Antropologia Social da Faculdade de Filosofia, Letras e Ciências Humanas da Universidade de São Paulo. São Paulo, 2015.

COLLIER, John. Antropologia visual: a fotografia como método de pesquisa. São Paulo: EPU/Edusp, 1973.

CUNHA, Edgar Barbosa; FERRAZ, Ana Lúcia.; HIKIJI, Rose Satiko. 0 vídeo e 0 encontro etnográfico. Cadernos de Campo, v. 15, n. 14/15, p. 287-297, 2006.

DUBOIS, Philippe. 0 ato fotográfico e outros ensaios. Tradução de Marina Appenzeller. 14a . edição. Campinas: Editora Papirus, 2014[1990].

GELL, Alfred. Art and agency: an anthropological theory. Oxford: Clarendon Press, 1998.

MARESCA, Sylvain. La photographie - Un miroir des sciences sociales. Paris: L'Harmattan, 1996.

MOREIRA LEITE, Miriam. Retratos de família. 3ª edição. São Paulo: Edusp, 2001 [1993].

MÜLLER, Regina. Tayngava, a noção de representação na arte gráfica Asuriní do Xingu. In: VIDAL, L. (0rg). Grafismo Indígena - Estudos de Antropologia Estética. São Paulo: Edusp, 1992, p. 231-248.

. Asuriní do Xingu, história e arte. 2a. edição. Campinas: Editora da Unicamp, 1993.

As crianças no processo de recuperação demográfica dos Asuriní do Xingu. In: Lopes da Silva, A.; Macedo, A. V.; Nunes, A. (Orgs). Crianças Indígenas, ensaios antropológicos. São Paulo: Global Editora, 2002. p. $188-209$. 
SOUZA, Maria Luiza Rodrigues. Nomes e história do contato entre os Asuriní do Xingu. 1994. Dissertação (Mestrado em Antropologia Social) - Programa de Pós-Graduação em Antropologia Social da Faculdade de Filosofia, Letras e Ciências Humanas da Universidade de São Paulo. São Paulo, 1994.

VERnANT, Jean- Pierre. Mito e Pensamento entre os Gregos. Rio de Janeiro: Ed. Paz e Terra, 1990[1973].

VILLELA, Alice. Das Acontecências: experiência e performance no ritual Asuriní. 2009. Dissertação (Mestrado em Artes) - Programa de Pós-Graduação em Artes do Instituto de Artes da Unicamp, Campinas, 2009.

"Quando a imagem é a pessoa ou a fotografia como objeto patogênico". In: Caiuby Novaes, S. (Org.). Entre Arte e Ciência - A fotografia na Antropologia. São Paulo: Edusp, 2015.

0 negativo e o positivo. A fotografia entre os Asuriní do Xingu. 2016. Tese. (Doutorado em Antropologia Social) - Programa de Pós-Graduação em Antropologia Social da Faculdade de Filosofia, Letras e Ciências Humanas da Universidade de São Paulo. São Paulo, 2016. 